\title{
Green Synthesis, Characterization and Antibacterial Activity of ZnO Nanoparticles
}

\section{Hrishikesh Upadhyaya ${ }^{1}$, Soumitra Shome ${ }^{2}$, Rajdeep Sarma ${ }^{1}$, Sujit Tewari ${ }^{3}$, Mrinal Kanti Bhattacharya ${ }^{1}$, Sanjib Kumar Panda ${ }^{4}$}

\author{
${ }^{1}$ Department of Botany, Cotton University, Panbazar, Guwahati, Assam, India \\ ${ }^{2}$ Department of Botany and Biotechnology, Karimganj College, Karimganj, Assam, India \\ ${ }^{3}$ Department of Physics, Karimganj College, Karimganj, Assam, India \\ ${ }^{4}$ Department of Life Science and Bioinformatics, Assam University, Silchar, Assam, India \\ Email: ^hkupbl_au@rediffmail.com
}

How to cite this paper: Upadhyaya, H., Shome, S., Sarma, R., Tewari, S., Bhattacharya, M.K. and Panda, S.K. (2018) Green Synthesis, Characterization and Antibacterial Activity of ZnO Nanoparticles. American Journal of Plant Sciences, 9, 1279-1291. https://doi.org/10.4236/ajps.2018.96094

Received: February 14, 2018

Accepted: May 25, 2018

Published: May 28, 2018

Copyright (C) 2018 by authors and Scientific Research Publishing Inc. This work is licensed under the Creative Commons Attribution International License (CC BY 4.0).

http://creativecommons.org/licenses/by/4.0/

\section{Open Access}

\begin{abstract}
In the present study, mehendi extract (Lawsonia inermis) was used for phytosynthesis of $\mathrm{ZnO}$ nanoparticles using $0.1 \mathrm{M} \mathrm{Zn}\left(\mathrm{NO}_{3}\right)_{2}$ as precursor under alkaline condition using $\mathrm{NaOH}$ with vigorous stirring for $2 \mathrm{~h}$. ZnO NPs obtained were characterized by UV-Vis spectroscopy, XRD, SEM and TEM that showed change in shape and size. Hexagonal particles were formed due to plant extract relative to the rod shaped particles in absence of plant extract. Further the antibacterial property of $\mathrm{ZnO} \mathrm{NP}$ synthesized by green method was more effective than those synthesized in absence of plant extract. The antibacterial activity study of both the synthesized $\mathrm{ZnO}$ nanoparticles reveals that the nanoparticles synthesized using mehendi extract are more effective than the particle synthesized without mehendi extract. Thus, the use of leaf extract as capping agent would improve the antibacterial property of $\mathrm{ZnO}$ nanoparticle. However, bacteriocidal effect of these nanoparticles varies with respect to the organism tested.
\end{abstract}

\section{Keywords}

Antibacterial Activity, Green Synthesis, ZnO Nanoparticles, Lawsonia inermis

\section{Introduction}

Nanotechnology is the art and science of manipulating matter at the nanoscale to create new and unique materials and products with enormous potential to change society [1]. Nanoparticles can serve as "magic bullets", containing herbicides, chemicals, or genes, which target plant parts to release the content [2] [3]. 
Nano-zinc oxide has been widely used in industry for various applications like leather manufacturing, rubber industry etc. [4] [5]. $\mathrm{ZnO}$ nanoparticle is also drawing researcher's attention for its wide application in medicine, foods, agriculture, solar cell and cosmetics because of its high antibacterial, prospect for nano-nutrition, refractive index, high thermal conductivity, and UV protection property respectively [1] [6] [7] [8].

Green synthesis or phytosynthesis of nanoparticle is an eco-friendly approach which is in common practice [9] [10] [11] [12] [13]. The phytosynthetic approach is a simple alternative to chemical and physical methods due to low cost and less use of toxic chemicals. $\mathrm{ZnO}$ is selected for the current experiment because of its wide biological applications. In the present study, leaf extract of Lawsonia inermis (Mehendi) was used because of its medicinal properties [14]. Plants are rich in pytochemical sparticulary secondary metabolites such as tannins, terpenoids, flavonoids that have been demonstrated to have antibacterial properties [14] [15]. In the present study, an attempt has been made to compare the antibacterial property of $\mathrm{ZnO}$ nanoparticle synthesized in the presence and absence of leaf extract of Lawsonia inermis (Mehendi). It is hypothesized that use of leaf extract as capping agent would improve the antibacterial property of $\mathrm{ZnO}$ nanoparticle.

\section{Materials and Methods}

\subsection{Plant Material}

In our experiment the leaves of Lawsonia inermis were collected from Karimganj, Assam, India washed properly and was allowed to dry at room temperature. The plant was authenticated by the subject expert Dr. Partha Sarathi Das, Department of Botany and Biotechnology, Karimganj College Karimganj, Assam, India and confirmed by comparing the same with existing herbarium of the Department of Botany and Biotechnology, Karimganj College Karimganj, Assam, India. The dry leaf powder was obtained using grinder and used to prepare the plant extract by mixing $1 \mathrm{~g}$ of the leaf powder in $10 \mathrm{ml}$ of distilled water and heated in a water bath at $100^{\circ} \mathrm{C}$ for $10 \mathrm{~min}$. The solution was then filtered using Whatman No.1 filter paper and the filtrate was stored at $4^{\circ} \mathrm{C}$ and used for $\mathrm{ZnO}$ NP synthesis. Different concentrations of the resulting filtrate $(0 \%, 2.5 \%, 5 \%$, $10 \%, 15 \%, 20 \%)$ were used as a reducing agent for $\mathrm{ZnO} \mathrm{NP}$ synthesis and $5 \%$ plant extract was selected based UV-Vis spectroscopic studies.

\subsection{ZnO NP-I \& ZnO NP-II Synthesis}

In this method we have dissolved $2.97 \mathrm{~g}(0.1 \mathrm{M})$ of $\mathrm{Zn}\left(\mathrm{NO}_{3}\right)_{2}$ salt in $90.7 \mathrm{ml}$ of double distilled water which was then titrated drop wise along the wall of the conical flask with $9.3 \mathrm{ml}$ of $2 \mathrm{M} \mathrm{NaOH}$ for $2 \mathrm{~h}$ under vigorous stirring at room temperature to obtain $100 \mathrm{ml}$ final volume after titration. After $2 \mathrm{~h}$ of vigorous stirring the solution was filtered through a filter paper and the residue in the form of $\mathrm{Zn}(\mathrm{OH})_{2}$ obtained was washed properly using double distilled water. 
The residue was then dried at $70^{\circ} \mathrm{C}$ in a hot air oven for $48 \mathrm{~h}$ to obtain fine $\mathrm{ZnO}$ $\mathrm{NP}$ powder. In the $\mathrm{ZnO} \mathrm{NP}-\mathrm{II}$ synthesis the above solution for $\mathrm{ZnO} \mathrm{NP}-\mathrm{I}$ was titrated with $5 \%$ plant extract along with $\mathrm{NaOH}$ drop wise and then filtered, washed and dried using the aforesaid method for $\mathrm{ZnO}$ NP-I.

\subsection{Characterization of $\mathrm{ZnO}$ Nanoparticle}

The above synthesized $\mathrm{ZnO} \mathrm{NP}$ was characterized using UV-Vis spectroscopy, SEM, TEM and XRD. The morphology was investigated using field emission scanning electron microscopy. For FESEM alcoholic dispersion of synthesized $\mathrm{ZnO} \mathrm{NP}$ was put on a properly cleaned glass slide followed by spin coating. $\mathrm{Uv}$-Vis spectroscopy of the sample was done using Biospectrometer (Eppendorf) in which $10 \mathrm{mg}$ of $\mathrm{ZnO} \mathrm{NP}$ was resuspended in $15 \mathrm{ml}$ distilled water and sonicated for $10 \mathrm{~min}$ after which the sample was scanned from wavelength $300-700$ nm.

X-Ray diffraction of the sample powder was carried out in a PANalytical X-PERT PRO applying a monochromator to select the Kal component of the employed copper radiation (Wavelength of $1.54056 \AA$ ). The data have been collected in the range $20-80$ with a step size of $5^{\circ}$. The XRD data has been depicted in Figure 3, the grain size of the synthesized sample have been collected using Scherrer formula [16]:

$$
D_{h k l}=\mathrm{K} \lambda / \beta_{p} \cos \theta
$$

where $D_{h k l}$ is the average grain size, $\mathrm{K}$ the shape factor (here, 0.9), $\lambda$ is the $\mathrm{x}$-ray wavelength, $\beta_{\mathrm{p}}$ is the full width at half maximum (FWHM) intensity (here, 101 and 002 peak of the $\mathrm{ZnO}$ nanoparticle $\mathrm{ZnO}$ NP-I and ZnO NP-II spectrum fitted with Gaussian for precision measurement and $\theta$ is the Bragg's angle.

For TEM analysis, powder samples were dispersed in triple distilled water using sonication, and a drop of the dispersion was placed onto a carbon coated copper grid and dried at room temperature. Further selected area electron diffraction (SAED) patterns were recorded to determine the growth orientation of the synthesized $\mathrm{ZnO}$ and was put into a uniform carbon coated copper TEM grid and dried in vacuum.

\subsection{Antibacterial Activity of ZnO Nanoparticles (ZnO NP-1 \& ZnO NP-II)}

The antimicrobial activity of both the synthesized $\mathrm{ZnO}$ nanoparticles was performed and their antimicrobial efficacy was compared against four bacterial strains (Escherichia Coli, Pseudomonas aeruginosa, Staphylococcus aureus, Bacillus subtilis). The lyophilized cultured of the four bacterial strains were revived in conical flasks containing $20 \mathrm{ml}$ of nutrient broth with $5 \mathrm{ml}$ of inoculum and incubated at $37^{\circ} \mathrm{C}$. From this revived bacterial culture $100 \mathrm{ul}$ of inoculum were added to $20 \mathrm{ml}$ of LB broth media followed by the addition of synthesized $\mathrm{ZnO}$ nanoparticle dispersion of concentration of $0 \mu \mathrm{g} / \mathrm{ml}, 100 \mu \mathrm{g} / \mathrm{ml}, 200 \mu \mathrm{g} / \mathrm{ml}$ and $500 \mu \mathrm{g} / \mathrm{ml}$ with respect to the total volume of $20 \mathrm{ml}$ (Figure 1). The inoculated 


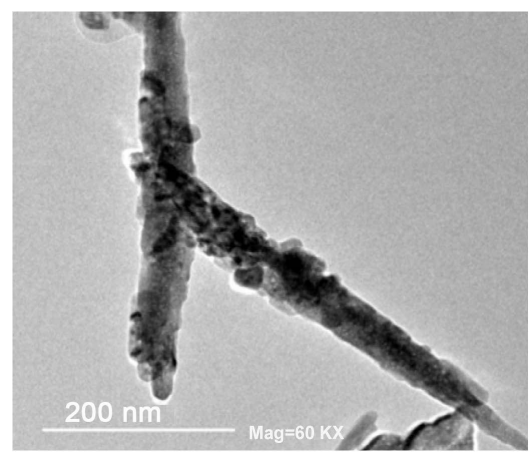

(a)

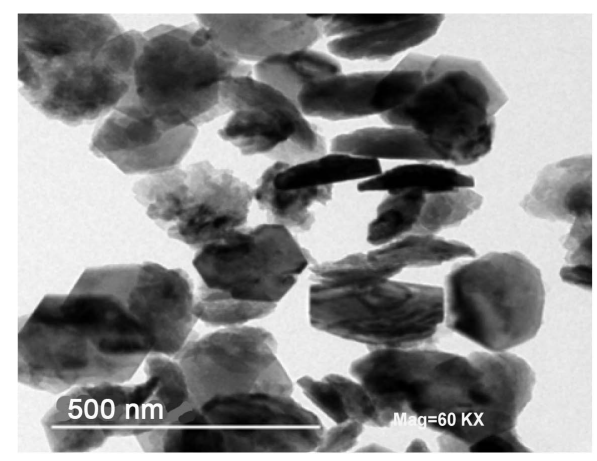

(b)

Figure 1. Transmission electron micrograph of synthesized $\mathrm{ZnO}$ nanoparticles in absence (ZnO NP-I) ((a) and (c)) and presence (ZnO NP-II) ((b) and (d)) of mehendi (Lawsonia inermis) extract by using Zinc nitrate as precursor.

culture were incubated at $37^{\circ} \mathrm{C}$ with gentle stirring. The growth of bacterial strains was observed in liquid medium by measuring absorbance at $600 \mathrm{~nm}$ against control using UV-VIS spectrophotometer [17].

\subsection{Statistical Analysis}

Each experiment was repeated thrice and data presented are mean \pm SE $(n=3)$ and least significance difference (LSD) test was used for comparison between pairs of treatments. The data analysis was carried out using a statistical package, SPSS v. 10 (SPSS Inc., Chicago, IL, USA).

\section{Results and Discussion}

\subsection{Synthesis and Characterization of ZnO NP-I and ZnO NP-II}

$\mathrm{ZnO}$ nanoparticles were synthesized by using leaf extract of Lawsonia inermis extract as detailed above. The size and morphology of the nanoparticles was characterized by using various techniques. The UV-Vis spectra for ZnO NP-I and $\mathrm{ZnO}$ NP-II are shown in Figure 2(a) and Figure 2(b) respectively which clearly shows a blue shift resulting from reduction in size from NP-I to NP-II.

The SEM morphology images of the ZnO NPs as synthesized without plant extract (NP-I) and with plant extract (NP-II) are shown in Figure 2(c) and Figure 2(d) respectively. The SEM images confirm formation of $\mathrm{ZnO}$ nano particles with hexagonal structures having sizes nearly $100 \mathrm{~nm}$ for ZnO NP-I and $75 \mathrm{~nm}$ for NP-II.

The TEM micro graphs also confirm the synthesized particles to be in the same range as predicted XRD and SEM. It also shows formation of hexagonal structures with average particle size decreased from $100 \mathrm{~nm}$ for ZnO NP I to 75 $\mathrm{nm}$ in $\mathrm{ZnO}$ NP II. The results are in good agreement with that of XRD and SEM analysis.

Structural analysis of the sample was made by X-ray Diffraction studies with $\mathrm{Cu} \mathrm{K} \mathrm{K}_{\alpha}$ radiation $(\lambda=1.5418 \AA)$ as X-ray source at $40 \mathrm{kV}$ and $30 \mathrm{~mA}$ in the scanning angle $(2 \theta)$ from $20^{\circ}$ to $80^{\circ}$. The resulted XRD pattern was analysed using 


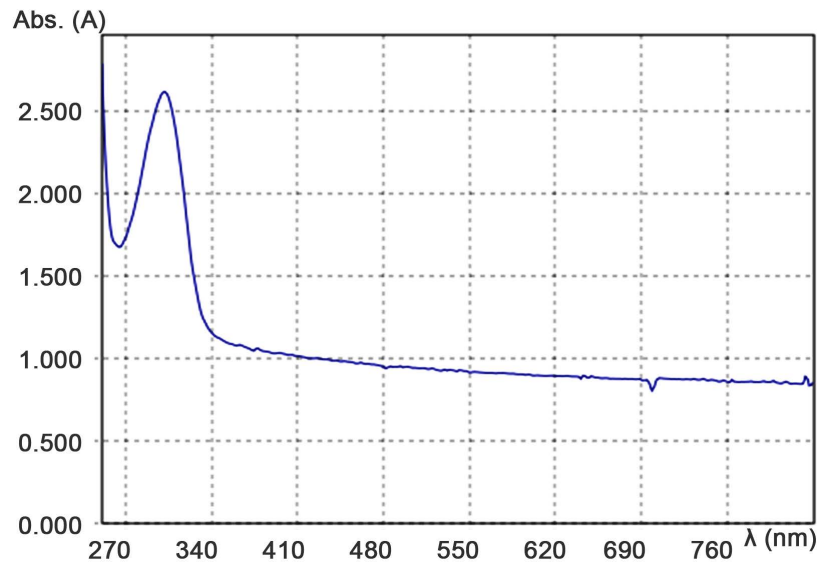

(a)

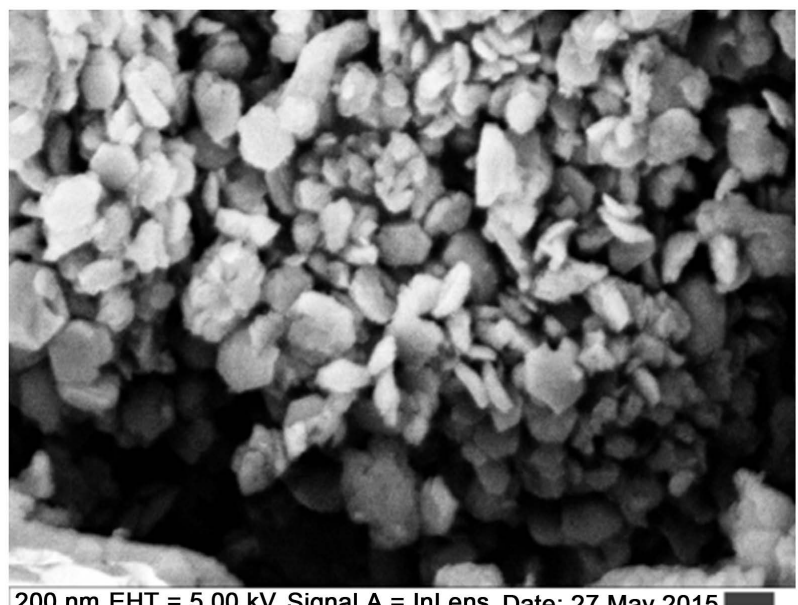

$200 \mathrm{~nm}$ EHT $=5.00 \mathrm{kV}$ Signal A = InLens Date: 27 May 2015 ZEISS WD $=5.5 \mathrm{~mm}$ Mag $=100.23 \mathrm{KX}$ Time: $16: 20: 55$

(c)

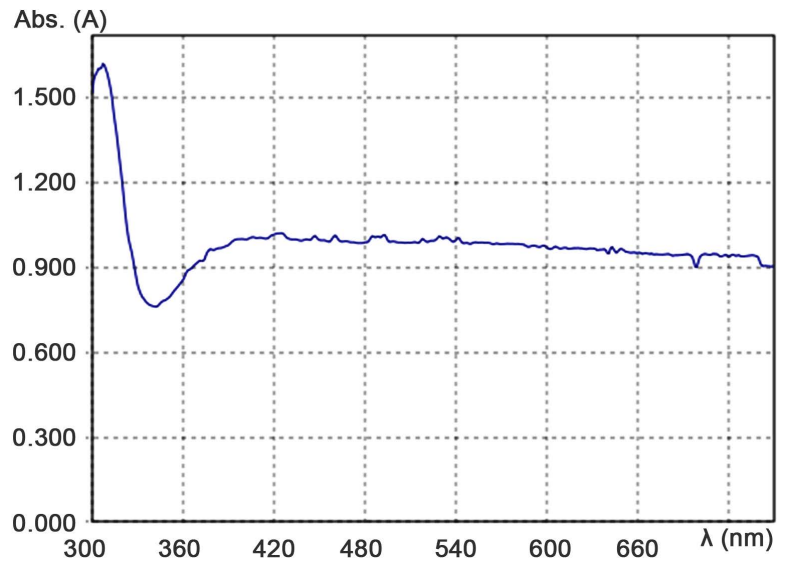

(b)

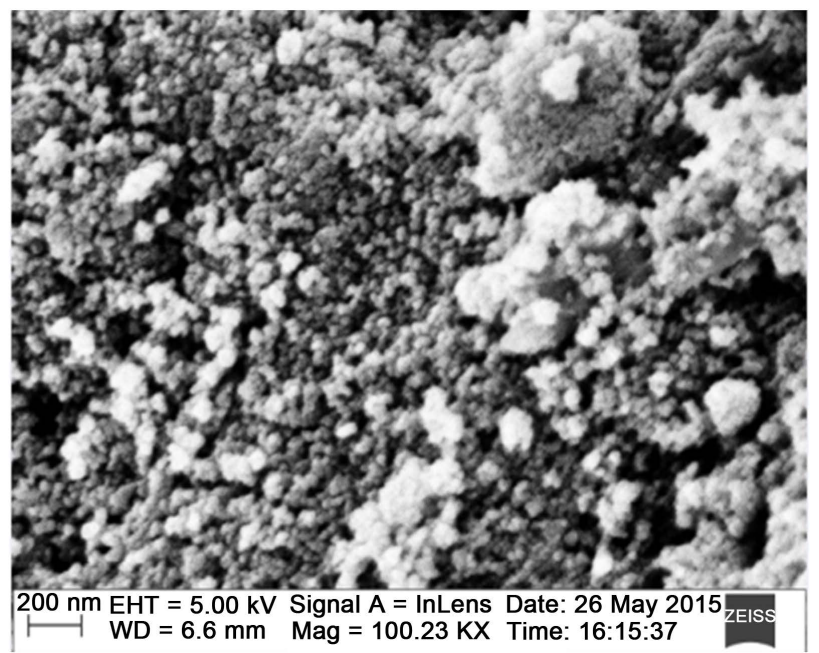

(d)

Figure 2. UV-visible spectra ((a) and (b)) and scanning electron micrograph ((c) and (d)) of synthesized ZnO nanoparticles in absence (ZnO NP-I) and presence (ZnO NP-II) of mehendi (Lawsonia inermis) extract by using Zinc nitrate as precausor.

X'Pert High Score software by search match tool, it was found to match with the ICDD Reference Pattern of Zinc Oxide, 01-070-8072.

As depicted in Figure 3(a) and Figure 3(b), typical XRD pattern of ZnO samples having polycrystalline nature with major peaks along the planes (100), (002), (101), (102), (110), (103), and (112). The highest intensity peak is found along the plane (101).Other peaks with lower intensities were observed along (200), (201), (004), (202) etc. The observed XRD pattern is analyzed, fitted and refined using X'Pert High Score software by search match tool, it was found to match with the ICDD Reference Pattern of Zinc Oxide, 01-070-8072. The ZnO NPs exhibit hexagonal phase (space group $\mathrm{p}_{3 \mathrm{mc}}$ ) with wurtzite structure $\mathrm{a}=$ $0.3329 \mathrm{~nm}, \mathrm{c}=0.5185 \mathrm{~nm}$.

\subsection{Antibacterial Activities of ZnO Nanoparticles against E. coli}

In case of $E$. coli the growth of bacterial populations has decreased significantly at $100 \mu \mathrm{g} / \mathrm{ml}$ and $200 \mu \mathrm{g} / \mathrm{ml} \mathrm{ZnO}$ nanoparticle relative to the control. Absorbency 


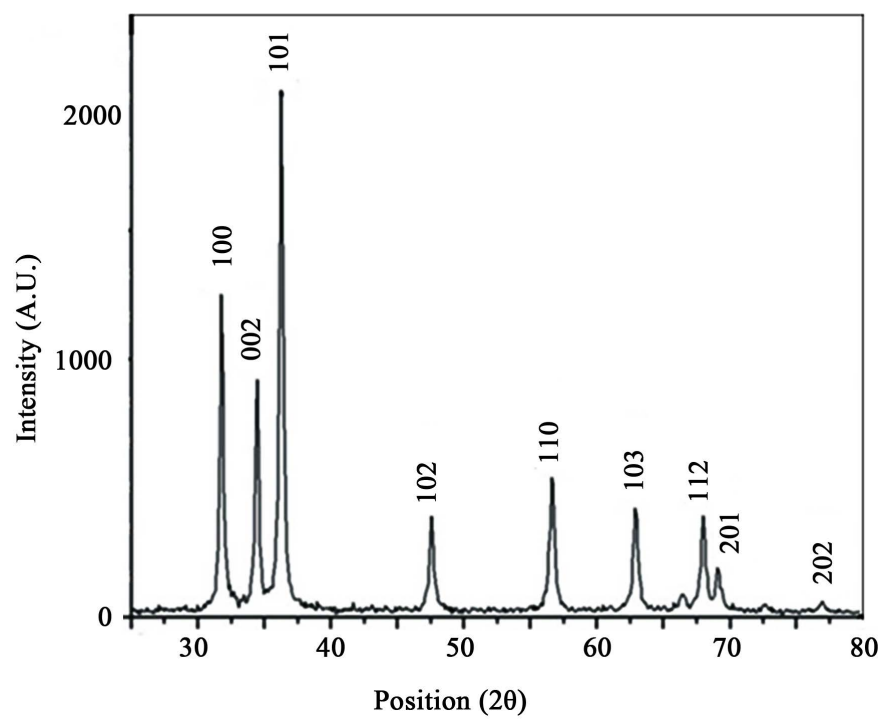

(a)

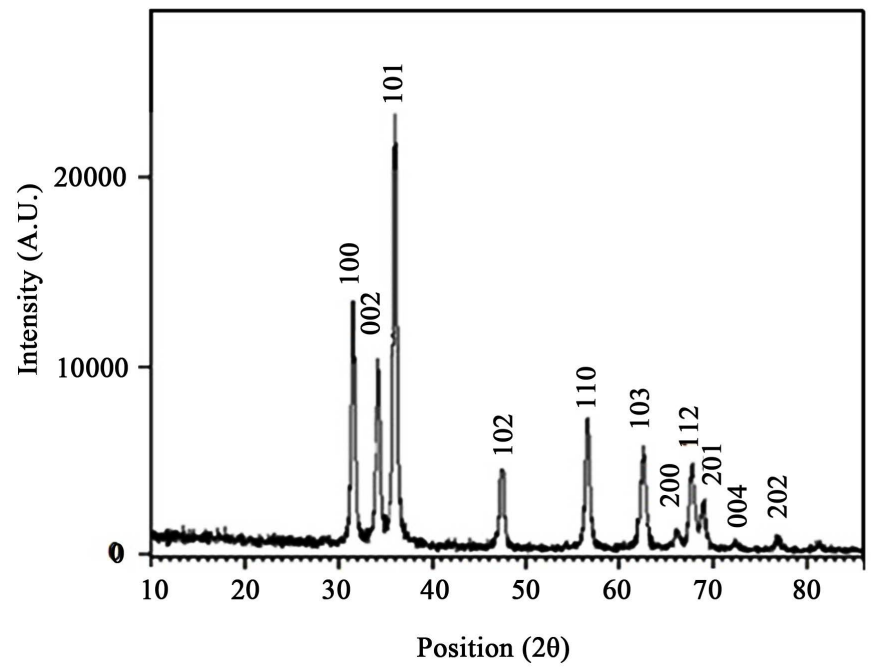

(b)

Figure 3. XRD pattern of $\mathrm{ZnO}$ nanoparticles synthesized in absence ( $\mathrm{ZnO} \mathrm{NP}-\mathrm{I}$ ) (a) and presence (ZnO NP-II) (b) of mehendi (Lawsonia inermis) extract by using Zinc nitrate as precausor.

readings taken on 1st, 2nd, 3rd, 4th, 5th, 6th and 24th hours suggest that 200 $\mu \mathrm{g} / \mathrm{ml}$ of both $\mathrm{ZnO}$ NP-I and $\mathrm{ZnO}$ NP-II nanoparticles show optimum antibacterial activity against $E$. coli. However when the antibacterial efficacy of $\mathrm{ZnO}$ NP-I and ZnO NP-II is compared readings suggest that ZnO NP-II has better antibacterial activity than $\mathrm{ZnO}$ NP-I compared to the control (Figure 4). Similarly $\mathrm{ZnO} \mathrm{NP}-\mathrm{II}$ nanoparticle at $500 \mu \mathrm{g} / \mathrm{ml}$ also showed enhanced anti-bacterial effect than ZnO NP-I on 1st-6th and 24th hour. The antibacterial activity of $\mathrm{ZnO}$ NP-I at $100 \mu \mathrm{g} / \mathrm{ml}$ is however slightly higher than that of ZnO NP-II compared to control. This enhanced anti-E. coli effect of ZnO NP-II is due to the synergistic effect of increased bioactive surface area of $\mathrm{ZnO}$ nanoplates with hexagonal shape synthesized using Lawsonia inermis extract and Lawsonia inermis extract 


\section{E coli}

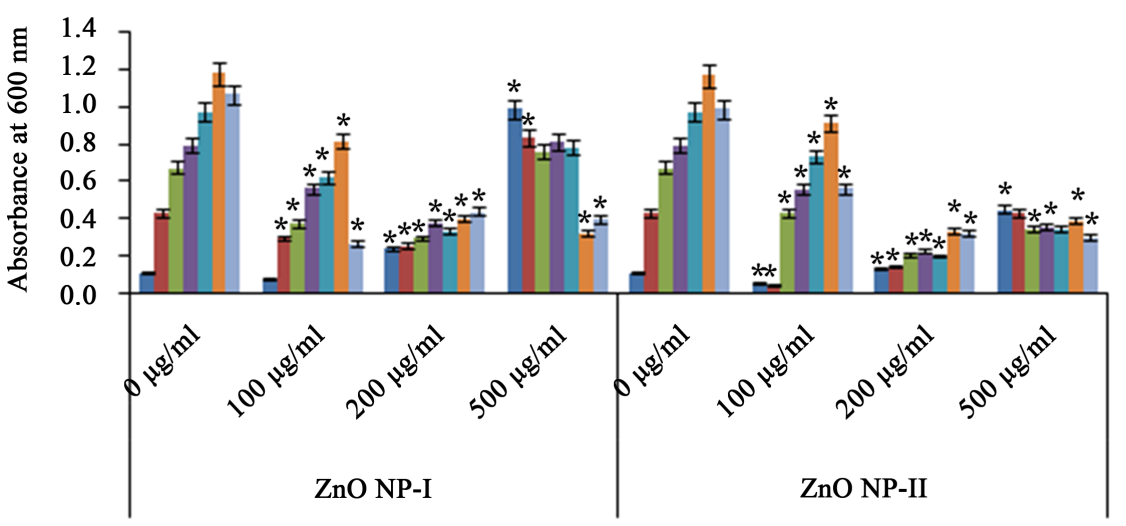

Figure 4. Antibacterial efficiency of $\mathrm{ZnO}$ NP-I and ZnO NP-I I nanoparticles at 0, 100, 200 and $500 \mu \mathrm{g} / \mathrm{mL}$ tested on $E$. coli after 1, 2, 3, 4, 5, $6 \& 24 \mathrm{~h}$ incubation. Data presented are mean \pm SE $(n=3)$. Bars superscript with “*” indicates significant mean difference from control $(0 \mathrm{mg} / \mathrm{ml})$ at $\mathrm{p}<0.05$ in multiple comparison by LSD test.

ingredients that ligated to $\mathrm{ZnO}$ nanoparticles (Zno NP-II). Guo et al. [18] also reported the increased antibacterial activity of Ta-doped $\mathrm{ZnO}$ nanoparticles having pure hexagonal wurtzite structure of polycrystalline $\mathrm{ZnO}$ nanoparticles that showed enhanced antibacterial activity due to increased bioactive surface of hexagonal Ta-doped plates compared to control non Ta-doped $\mathrm{ZnO}$ nanoparticles. Liu et al., demonstrated the antibacterial effect of $\mathrm{ZnO}$ nanoparticles against Escherichia coli and found that the effect increases with increase in $\mathrm{ZnO}$ nanoparticle concentration [19]. Previous report suggest that acetate and ethanol extracts $L$. inermis expressed tremendous antibacterial activity against E.coli (gram negative bacteria) confirming the antibacterial potential of L. inermis [20] [21]. The combined antibacterial effect of individual $\mathrm{ZnO}$ nanoparticle and L.inermis resulted in enhanced antibacterial effect of $\mathrm{ZnO}$ NP-II nanocomposites. Recently Moghaddam et al., [22] reported that appreciable antibacterial activity of green synthesized $\mathrm{ZnO}$ nanoparticles was achieved against $E$. coli at 100 $\mu \mathrm{g} / \mathrm{ml}$ concentration.

\subsection{Antibacterial Activity of ZnO Nanoparticles against $P$. aeruginosa}

The antibacterial activity of ZnO NP-I and ZnO NP-II against $P$. aeruginosa is appreciable at $100 \mu \mathrm{g} / \mathrm{ml}, 200 \mu \mathrm{g} / \mathrm{ml}$ and $500 \mu \mathrm{g} / \mathrm{ml}$ concentration compared to control with $100 \mu \mathrm{g} / \mathrm{ml}$ and $200 \mu \mathrm{g} / \mathrm{ml}$ showing very good antibacterial effect relative to control on 1st, $2 \mathrm{nd}, 3 \mathrm{rd}, 4$ th, 5 th and 6 th hour (Figure 5). Lee et al., [23] reported the antibacterial effect of $\mathrm{ZnO}$ nanoparticles bio-fabricated with $C$. religiosum (L.) against virulent Pseudomonas aeruginosa that inhibited Pseudomonas aeruginosa induced biofilm formation. Similarly Mahendra et al., [24] demonstrated the antibacterial effect of $\mathrm{ZnO}$ nanoparticles coated with $C$. religiosum against $P$. aeruginosa with MIC of $312.5 \mu \mathrm{g} / \mathrm{ml}$ and $20.33 \mathrm{~mm}$ zone of 


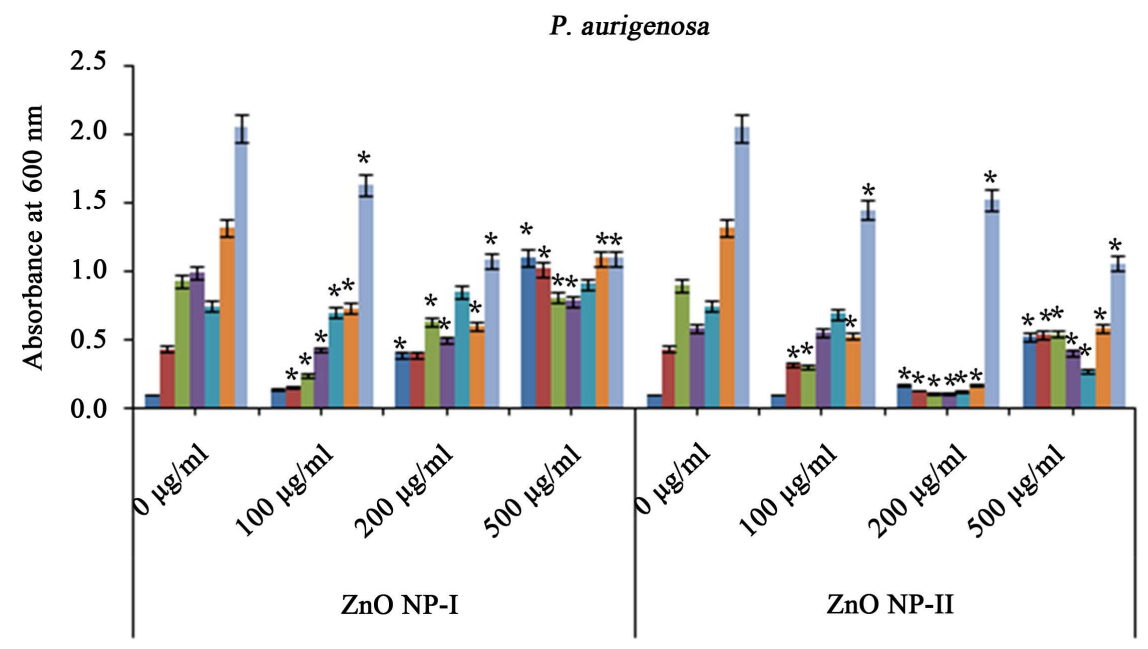

Figure 5. Antibacterial efficiency of ZnO NP-I and ZnO NP-I I nanoparticles at 0, 100, 200 and $500 \mu \mathrm{g} / \mathrm{mL}$ tested on $P$. aurigenosa after 1, 2, 3, 4, 5, $6 \& 24 \mathrm{~h}$ incubation. Bars superscript with "*” indicates significant mean difference from control $(0 \mathrm{mg} / \mathrm{ml})$ at $\mathrm{p}<$ 0.05 in multiple comparison by LSD test.

inhibition which supports the present findings. At $24^{\text {th }}$ hour the high absorbancy of the bacterial culture may be due to the formation of cell debris and toxic substances that increased the turbidity of the bacterial culture media. ZnO NP-II synthesized using Lawsonia inermis extract has enhanced antibacterial efficiency than $\mathrm{ZnO}$ NP-I which is due to the synergistic antibacterial effect of both heaxagonal wurtzite structure ZnO NP-II nanoparticles (as suggested by TEM images) that resulted in enhanced surface bioactivity and Lawsonia inermis derived bioactive compounds that ligated to the ZnO NP-II nanoparticles. Similar to our findings Guo et al., [18] also reported the enhanced antibacterial activity of Ta-doped $\mathrm{ZnO}$ nanoparticles that showed pure hexagonal wurtzite structure of polycrystalline $\mathrm{ZnO}$ nanoparticles that showed enhanced antibacterial activity due to increased bioactive surface of hexagonal Ta-doped plates compared to control non Ta-doped $\mathrm{ZnO}$ nanoparticles. Habbal et al., [14] also reported the high in-vitro anti- $P$. aeruginosa activity of L. inermis which support our present findings. Similarly Al-Rubiay et al., [25] and Jeyaseelan et al., [20] demonstrated the antibacterial effect of alcoholic extract of Lawsonia inermis with MIC values of $0.5-0.57 \mu \mathrm{g} / \mathrm{ml}$. Naseem et al., [26] demonstrated the antibacterial activity of iron nanoparticle synthesized using Lawsonia inermis and Gardenia jasminoides leaves extract confirming the antibacterial potential of metal nanoparticles and L.inermis nanocomposites. Literature survey suggests that few reports are available on the antibacterial study of $\mathrm{ZnO}$ nanoparticles and $L$. inermis nanocomposites to directly support our study.

\subsection{Antibacterial Activity of Synthesized ZnO Nanoparticles against $S$, aureus}

The present study of antibacterial activity of Zno NP-I and ZnO NP-II against Staphylococcus aureus suggest that both ZnO NP-I and ZnO NP-II have a little 
retarded antibacterial effect against $S$. aureus compared to other three bacteria in the present study (Figure 5). However ZnO NP-II at $100 \mu \mathrm{g} / \mathrm{ml} 200 \mu \mathrm{g} / \mathrm{ml}$ and $500 \mu \mathrm{g} / \mathrm{ml}$ concentrations shows a little improved anti-Staphylococcus aureus activity on 1st, 2nd, 3rd, 4th, 5th and 6th hour than ZnO NP-I compared to control which is due to the synergistic antibacterial mechanisms of $\mathrm{ZnO}$ nanoparticle and Lawsonia inermis bioactive compounds that ligated to the $\mathrm{ZnO}$ nanoparticle surface and differences in the shape of $\mathrm{ZnO} \mathrm{NP}$-I which are nanorods while the ZnO NP-II being hexagonal plates may have easily penetrated the membrane barrier mediating bacterial membrane damage and cell leakage leading to cell death. In context to this Badoni et al., [27] reported that $\mathrm{ZnO}$ nanoparticles bio-fabricated with $R$. parviflora extract showed very good anti-Staphylococcus aureus activity at $200 \mu \mathrm{g} / \mathrm{ml}$ concentration (Badoni et al., [27]. The anti-Staphylococcus aureus activity of $\mathrm{ZnO}$ nanoparticle and Lawsonia inermis nanocomposites (ZnO NP-II) has increased with rise in concentration. Karvani et al., also reported a similar increase in anti-Staphylococcus aureus activity of $\mathrm{ZnO}$ nanoparticles with increasing $\mathrm{ZnO}$ nanoparticle concentrations [28].

\subsection{Antibacterial Activity of ZnO Nanoparticles against B. subtilis}

Our study suggests that both ZnO NP-I and ZnO NP-II showed significant anti-Bacillus subtilis effect with $100 \mu \mathrm{g} / \mathrm{ml}$ and $200 \mu \mathrm{g} / \mathrm{ml}$ showing optimum antibacterial activity on $1^{\text {st }}, 2^{\text {nd }}, 3^{\text {rd }}, 4^{\text {th }}, 5^{\text {th }}$ and $6^{\text {th }}$ hour (Figure 6 and Figure 7). In this case also $\mathrm{ZnO}$ NP-II has enhanced anti-Bacillus subtilis efficacy than $\mathrm{ZnO}$ NP-I again suggesting the combined antibacterial effect of individual $\mathrm{ZnO}$ nanoparticle having increased surface bioactivity than ZnO NP-I and Lawsonia inermis derived bioactive ingredient that got ligated on $\mathrm{ZnO}$ nanoparticle. Hsueh

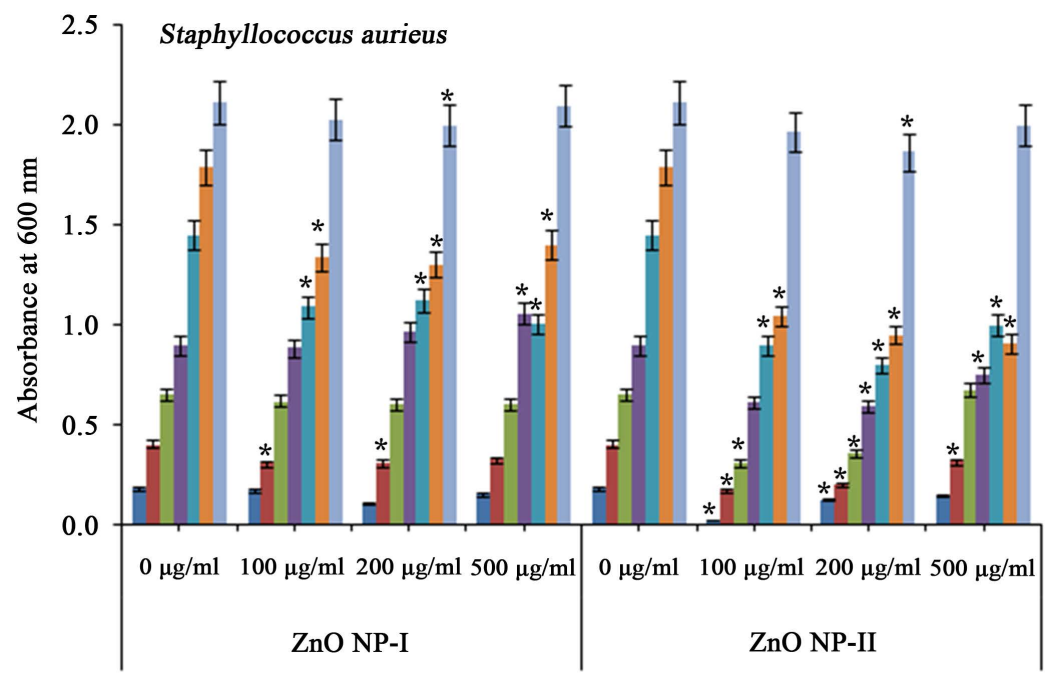

Figure 6. Antibacterial efficiency of $\mathrm{ZnO}$ NP-I and ZnO NP-I I nanoparticles at 0, 100, 200 and $500 \mu \mathrm{g} / \mathrm{mL}$ tested on Staphyllococcus aurieus after 1, 2, 3, 4, 5, 6 \& $24 \mathrm{~h}$ incubation. Bars superscript with " $*$ " indicates significant mean difference from control (0 $\mathrm{mg} / \mathrm{ml}$ ) at $\mathrm{p}<0.05$ in multiple comparison by LSD test. 


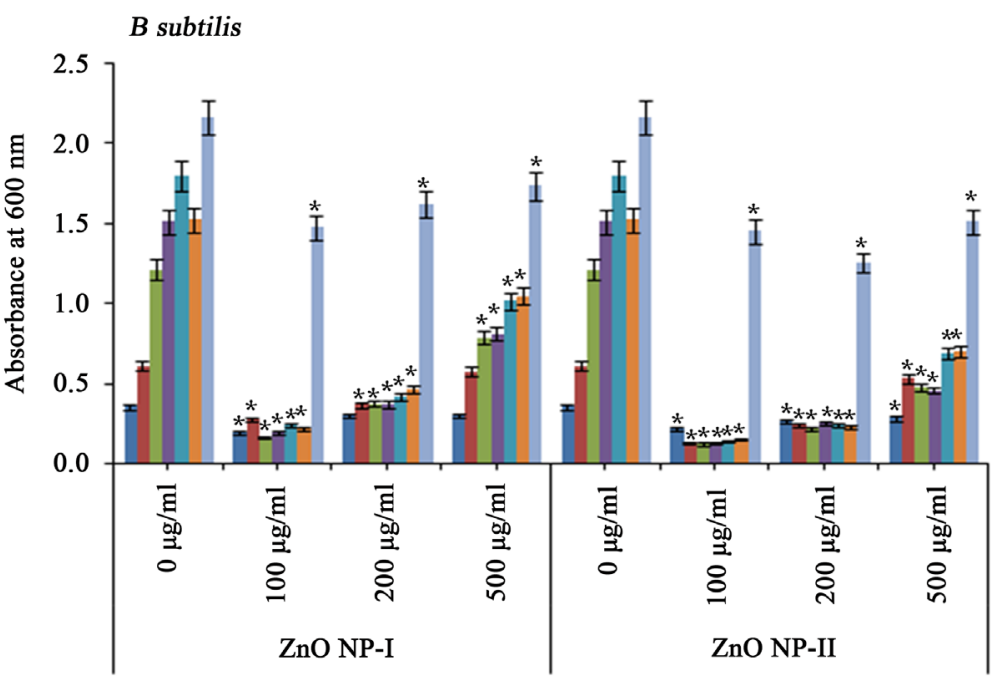

Figure 7. Antibacterial efficiency of ZnO NP-I and ZnO NP-I I nanoparticles at 0, 100, 200 and $500 \mu \mathrm{g} / \mathrm{mL}$ tested on $B$ subtilis after 1, 2, 3, 4, 5, $6 \& 24 \mathrm{~h}$ incubation. Bars superscript with “ " indicates significant mean difference from control $(0 \mathrm{mg} / \mathrm{ml})$ at $\mathrm{p}<0.05$ in multiple comparison by LSD test.

et al., [29] and Mastanaiah et al. [30] demonstrated the anti-Bacillus subtilis activity of $\mathrm{ZnO}$ nanoparticle and Lawsonia inermis respectively suggesting the antibacterial potential of $\mathrm{ZnO}$ nanoparticle and Lawsonia inermis.

\section{Conclusion}

$\mathrm{ZnO}$ NPs have potential antibacterial property that may be attributed to its various structural and functional properties. The antibacterial activity study of both the synthesized $\mathrm{ZnO}$ nanoparticles reveals that the nanoparticles synthesized using mehendi extractare are more effective than the particle synthesized without mehendi extract. Thus, the use of leaf extract as capping agent would improve the antibacterial property of $\mathrm{ZnO}$ nanoparticle. However, bacteriocidal effect of these nanoparticles varies with respect to the organism tested. Detail understanding of the molecular mechanism of the synthesized nanoparticles may help to modulate their antibacterial potential for the benefit of mankind.

\section{Acknowledgements}

The authors thankfully acknowledged the financial support from the DBT, Govt of India, under RGYI, Scheme (SAN No. 102/IFD/SAN/1716/2013-2014) and for the supply of rice seeds by Regional Agricultural Research Station (RARS), Akbarpur, Karimganj throughout the experiment. The authors are thankful to the Director, Institute of Advanced Study in Science and Technology (IASST), Guwahati 781035, Assam, India for allowing SEM and X-ray difraction analysis of $\mathrm{ZnO} \mathrm{NP}$ at central instrumentation facility (CIF) of IASST.

\section{References}

[1] Krause, M. (2014) Introduction to Nanotechnology, supported by VERITOX ser- 
vices, Toxicology and Industrial Hygiene. https://www.aiha.org/aihce07/handouts/rt201krause.pdf

[2] Pérez-de-Luque, A. and Rubiales, D. (2009) Nanotechnology for Parasitic Plant Control. Pest Management Science, 65, 540-545. https://doi.org/10.1002/ps.1732

[3] Fawcett, D., Verduin, J.J., Shah, M., Sharma, S.B. and Poinern, G.E.J. (2017) A Review of Current Research into the Biogenic Synthesis of Metal and Metal Oxide Nanoparticles via Marine Algae and Seagrasses. Journal of Nanoscience, 2017, 1-15. https://doi.org/10.1155/2017/8013850

[4] Nawaz, H.R., Solangi, B.A., Zehra, B. and Nadeem, U. (2011) Preparation of Nano Zinc Oxide and Its Application in Leather as a Retanning and Antibacterial Agent. Canadian Journal on Scientific and Industrial Research, 2, 164-170

[5] Haq, A.N.U., Nadhman, A., Ullah, I., Mustafa, G., Yasinzai, M. and Khan, I. (2017) Synthesis Approaches of Zinc Oxide Nanoparticles: The Dilemma of Ecotoxicity. Journal of Nanomaterials, 2017, 1-14. https://doi.org/10.1155/2017/8510342

[6] Wang, Z.L., Kong, X.Y., Ding, Y., Gao, P., Hughes, W.L., Yang, R. and Zhang, Y. (2004) Semiconducting and Piezoelectric Oxide Nanostructures Induced by Polar Surfaces. Advanced Functional Materials, 14, 943-956.

https://doi.org/10.1002/adfm.200400180

[7] Brayner, R., Ferrari-Iliou, R., Brivois, N., Djediat, S., Benedetti, M.F. and Fiévet, F. (2006) Toxicological Impact Studies Based on Escherichia coli Bacteria in Ultrafine ZnO Nanoparticles Colloidal Medium. Nano Letters, 6, 866-870.

https://doi.org/10.1021/nl052326h

[8] Zhang, L., Ding, Y., Povey, M. and York, D. (2008) ZnO Nanofluids: A Potential Antibacterial Agent. Progress in Natural Science, 18, 939-944.

https://doi.org/10.1016/j.pnsc.2008.01.026

[9] Jalal, R., Goharshadi, E.K., Abareshi, M., Moosavi, M., Yousefi, A. and Nancarrow, P. (2010) ZnO Nanofluids: Green Synthesis, Characterization, and Antibacterial Activity. Materials Chemistry and Physics, 121, 198-201. https://doi.org/10.1016/j.matchemphys.2010.01.020

[10] Sathya, A. and Ambikapathy, V. (2012) Studies on the Phytochemistry, Antimicrobial Activity and Green Synthesis of Nanoparticles using Cassia tora L. Drug Invent Today, 4, 408-410.

[11] Hudlikar, M., Joglekar, S., Dhaygude, M. and Kodam, K. (2012) Latex-Mediated Synthesis of ZnS Nanoparticles: Green Synthesis Approach. Journal of Nanoparticle Research, 14, 1-6. https://doi.org/10.1007/s11051-012-0865-x

[12] Hussain, I., Singh, N.B., Singh, A., Singh, H. and Singh, S.C. (2016) Green Synthesis of Nanoparticles and Its Potential Application. Biotechnology Letters, 38, 545-560. https://doi.org/10.1007/s10529-015-2026-7

[13] Balasooriya, E.R., Jayasinghe, C.D., Jayawardena, U.A., Ruwanthika, R.W.D., Mendis de Silva, R. and Udagama, P.V. (2017) Honey Mediated Green Synthesis of Nanoparticles: New Era of Safe Nanotechnology. Journal of Nanomaterials, 2017, 1-10. https://doi.org/10.1155/2017/5919836

[14] Habbal, O., Hasson, S.S., El-Hag, A.H., Al-Mahrooqi, Z., Al-Hashmi, N., Al-Bimani, Z., Al-Balushi, M.S. and Al-Jabri, A.A. (2011) Antibacterial Activity of Lawsonia inermis Linn (Henna) against Pseudomonas aeruginosa. Asian Pacific Journal of Tropical Biomedicine, 1, 173-176. https://doi.org/10.1016/S2221-1691(11)60021-X

[15] Kannahi, M. and Vinotha, K. (2013) Antimicrobial Activity of Lawsonia inermis Leaf Extracts against Some Human Pathogens. International Journal of Current Microbiology and Applied Sciences, 2, 342-349. 
[16] Kumari, N., Ghosh, A., Tewari, S. and Bhattacharjee, A. (2013) Structural, Electrical and Optical Properties of Sintered $\mathrm{SnO}_{2}$ Pellets. Materials Science in Semiconductor Processing, 16, 905-914. https://doi.org/10.1016/j.mssp.2013.01.018

[17] Dutta, R.K., Sharma, P.K., Bhargava, R., Kumar, N. and Pandey, A.C. (2010) Differential Susceptibility of Escherichia coli Cells toward Transition Metal-Doped and Matrix-Embedded ZnO Nanoparticles. The Journal of Physical Chemistry B, 114, 5594-5599. https://doi.org/10.1021/jp1004488

[18] Guo, B.L., Han, P., Guo, L.C., Cao, Y.Q., Li, A.D., Kong, J.Z., Zhai, H.F. and Wu, D. (2015) The Antibacterial Activity of Ta-Doped ZnO Nanoparticles. Nanoscale Research Letters, 10, 336. https://doi.org/10.1186/s11671-015-1047-4

[19] Liu, Y., He, L., Mustapha, A., Li, H., Hu, Z.Q. and Lin, M. (2009) Antibacterial Activities of Zinc Oxide Nanoparticles against Escherichia coli O157:H7. Journal of Applied Microbiology, 107, 1193-1201.

[20] Jeyaseelan, E.C., Jenothiny, S., Pathmanathan, M.K. and Jeyadevan, J.P. (2012) Antibacterial Activity of Sequentially Extracted Organic Solvent Extracts of Fruits, Flowers and Leaves of Lawsonia inermis L. from Jaffna. Asian Pacific Journal of Tropical Biomedicine, 2, 798-802. https://doi.org/10.1016/S2221-1691(12)60232-9

[21] Bhuiyan, M.A.R., Islam, A., Islam, S., Hossain, A. and Nahar, K. (2017) Improving Dyeability and Antibacterial Activity of Lawsonia inermis L. on Jute Fabrics by Chitosan Pretreatment. Textiles and Clothing Sustainability, 3, 1.

https://doi.org/10.1186/s40689-016-0023-4

[22] Moghaddam, A.B., Moniri, M., Azizi, S., Rahim, R.A., Ariff, A.B., Saad, W.Z., Namvar, F., Navaderi, M. and Mohamad, R. (2017) Biosynthesis of ZnO Nanoparticles by a New Pichia Kudriavzevii Yeast Strain and Evaluation of Their Antimicrobial and Antioxidant Activities. Molecules, 22, E872.

[23] Lee, J.H., Kim, Y.G., Cho, M.H. and Lee, J. (2014) ZnO Nanoparticles Inhibit Pseudomonas aeruginosa Biofilm Formation and Virulence Factor Production. Microbiological Research, 169, 888-896. https://doi.org/10.1016/j.micres.2014.05.005

[24] Mahendra, C., Murali, M., Manasa, G., Ponnamma, P., Abhilash, M.R., Lakshmeesha, T.R., Satish, A., Amruthesh, K.N. and Sudarshana, M.S. (2017) Antibacterial and Antimitotic Potential of Bio-Fabricated Zinc Oxide Nanoparticles of Cochlospermum religiosum (L.). Microbial Pathogenesis, 110, 620-629.

https://doi.org/10.1016/j.micpath.2017.07.051

[25] Al-Rubiay, K.K., Jaber, N.N., Al-Mhaawe, B.H. and Alrubaiy, L.K. (2008) Antimicrobial Efficacy of Henna Extracts. Oman Medical Journal, 23, 253-256.

[26] Naseem, T. and Farrukh, M.A. (2015) Antibacterial Activity of Green Synthesis of Iron Nanoparticles Using Lawsonia inermis and Gardenia jasminoides Leaves Extract. Journal of Chemistry, 2015, Article ID: 912342. https://doi.org/10.1155/2015/912342

[27] Badoni, P.P., Kumar, G., Purohit, R., Singh, M. and Khajuria, A.K. (2016) Antibacterial Activity of Biosynthesized ZnO Nanoparticles against Gram Positive (Staphylococcus aureus) and Gram Negative (Pseudomonas aeruginosa) Bacteria: A Comparative Study. International Journal of Advanced Research, 4, 1804-1808. https://doi.org/10.21474/IJAR01/2585

[28] Karvani, Z.E. and Chehrazi, P. (2011) Antibacterial Activity of ZnO Nanoparticle on Gram-Positive and Gram-Negative Bacteria. African Journal of Microbiology Research, 5, 1368-1373.

[29] Hsueh, Y.H., Ke, W.J., Hsieh, C.T., Lin, K.S., Tzou, D.Y. and Chiang, C.L. (2015) $\mathrm{ZnO}$ Nanoparticles Affect Bacillus subtilis Cell Growth and Biofilm Formation. 
PLoS ONE, 10, e0128457. https://doi.org/10.1371/journal.pone.0128457

[30] Mastanaiah, J., Prabhavathi, N.B. and Varaprasad, B. (2011) Invitroanti-Bacterial Activity of Leaf Extracts of Lawsonia inermis. International Journal of PharmTech Research, 3, 1045-1049. 